\title{
ETHNIC DIVERSITY, PUBLIC SPENDING, AND INDIVIDUAL SUPPORT FOR THE WELFARE STATE: A REVIEW OF THE EMPIRICAL LITERATURE
}

\author{
Holger Stichnoth \\ ZEW Mannheim
}

\author{
Karine Van der Straeten \\ Toulouse School of Economics, CNRS, GREMAQ and IDEI
}

\begin{abstract}
We review the empirical literature that studies the effect of ethnic diversity on public spending and on individual support for the welfare state. The survey puts a particular focus on the fast-growing literature that uses experiments to study the effects of ethnic diversity. Many of these studies have appeared since the pioneering survey by Alesina and La Ferrara and have not been covered by a survey before.
\end{abstract}

Keywords. Experiments; Immigrants; Immigration; Social security; Welfare state

\section{Introduction}

There is a large literature on the costs and benefits of immigration within a given system of social security; see Rowthorn (2008) for a recent survey. More recently, economists have begun to address a related question: do immigration and, more generally, ethnic diversity in turn change this system of social security?

The question is delicate and important. Many European countries, for instance, have experienced large-scale immigration over the last five decades, often from countries with cultural, religious, or ethnic backgrounds which are quite different from those of the native population. Alesina and Glaeser (2004, p. 11) argue that this inflow will affect the European welfare state: 'one natural implication of our conclusion that fractionalization reduces redistribution is that if Europe becomes more heterogeneous due to immigration, ethnic divisions will be used to challenge the generous welfare state'. The possibility of such a trade-off is increasingly recognized and discussed within the political Left, which traditionally tends to be both pro-redistribution and pro-immigration; see for instance Gitlin (1996), Goodhart (2006), and the debate in Van Parijs (2004).

A number of empirical studies suggest that ethnic diversity does indeed matter for both actual public spending and individual attitudes and behaviour. The purpose of this paper is to survey this empirical literature. We cover some of the same material as in the survey by Alesina and La Ferrara (2005a), but put a particular focus on recent studies that have appeared in the last five years. In particular, we review the fast-growing literature which uses controlled experiments to study the effects of ethnic diversity 
on individual behaviour. We also review some very recent studies which use the natural experiment of refugee placement programs to identify the causal effect that the regional share of ethnic diversity has on actual public spending and on individual attitudes and behaviour. The issue of causality versus correlation is one of the main themes of the survey; the other critical issues in the literature are the definition and measurement of ethnic diversity, and the precise identification of why and how ethnic diversity matters for individual attitudes and behaviour.

Our survey attempts to bring together empirical contributions from several different literatures ranging from experimental economics to the comparative welfare state literature in sociology and political science - that have to some extent developed in isolation. By contrast, we leave aside some strands of the literature which have been well summarized by Alesina and La Ferrara (2005a), such as the role of ethnic diversity in the formation of political jurisdictions. We should also note that our survey does not cover all aspects of the relationship between ethnic diversity and the welfare state. We focus on public spending and on individual support for it. The survey by Nannestad (2007) has only a brief section on these issues, but covers important additional aspects such as the role of the welfare state in the migration decision (the 'welfare magnet' debate), the net fiscal effect of immigration, and the question of whether the welfare state slows down the integration of immigrants. Other recent articles complementary to ours are the reviews by Okkerse (2008) and by Longhi et al. (2005, 2009), which focus on the labour market impacts of immigration.

The outline of this paper is as follows. In Section 2, we survey the literature on the effects of ethnic diversity on public spending. Section 3 then looks at one of the building blocks behind this aggregate relationship, namely the effect of ethnic diversity on individual attitudes and behaviour. As noted, we will review both studies using observational data and studies that use data from experiments. Section 4 concludes.

\section{Ethnic Diversity and Public Spending}

A large number of studies have investigated the association between ethnic diversity and public spending, both across countries (Section 2.1) and at the subnational level, mainly across cities and states within the United States (Section 2.2).

\subsection{Cross-Country Evidence}

Alesina et al. (2001) argue that ethnic diversity is a key factor in explaining why the United States does not have a European-style welfare state (see also Alesina and Glaeser (2004) for a book-length treatment). They show that some prominent economic explanations alone cannot explain the difference and point to the influence that political institutions have on the size and the design of the welfare state. Alesina et al. argue that ethnic diversity not only helps explain why the United States has more property-friendly institutions, but that its negative influence on redistribution holds even for a given set of institutions.

To support this argument, they regress social spending as a share of GDP on an indicator of ethnolinguistic fractionalization (see below for a discussion of this variable) while controlling for a number of variables from Persson and Tabellini (2000): GDP per capita, the percent of the population aged 15-64, a dummy for a majoritarian election system, and dummies for Caribbean, Asian, and Latin American countries. The regression is cross-sectional: social spending over GDP is the average for 1960-1998, and ethno-linguistic fractionalization was measured in the 1960s. Alesina et al. do not find a significant relationship between the share of social spending over GDP and ethno-linguistic fractionalization. However, they show that a variable of racial fractionalization (measured over the 1990s) is negatively related to social spending as a share of GDP. ${ }^{1}$ The coefficient on racial fractionalization is now the 
only coefficient in the regression that is statistically significant. The association seems rather strong: if the probability that two people drawn at random from the population will belong to two different racial groups increases by one percentage point, the share of social spending over GDP is estimated to be lower by 7.5 percentage points.

In an early study, Mueller and Murrell (1986) find for a sample of OECD countries and a few other countries with 'sufficiently democratic institutions' (p. 136) that the total amount of public spending is negatively related to a country's ethnic diversity. James (1993) shows that ethno-linguistic and especially religious diversity are associated with a greater share of private schools in total enrollments. McCarty (1993) finds that in countries with greater ethnic and religious diversity, the (central) government spends less on transfers; other government expenditure is unaffected by ethnic and religious diversity. In a study by Kuijs (2000), ethnic diversity, as measured by ethno-linguistic fractionalization, is negatively related to health spending and to public spending on education. He also finds a negative correlation between ethnic diversity and indicators of health and education even when the amount of money spent on these areas is controlled for. Kuijs interprets this finding as suggesting that what he calls the 'technical efficiency' of public spending may be lower in ethnically diverse countries. More recently, Soroka et al. (2006) have studied the relationship between immigration and the share of social spending over GDP. They find that the change in social spending between 1970 and 1998 is negatively related to the change in the population share of immigrants over the period. However, there is no evidence that the change in social spending is associated with the level of the immigrant share in 1970.

Banting and Kymlicka (2004) study whether there is a trade-off between multicultural policies (as opposed to immigration or ethnic diversity per se) and a large welfare state. ${ }^{2}$ The possibility of such a trade-off is increasingly recognized and discussed within the political Left, which traditionally tends to be both pro-redistribution and pro-immigration. Critics worry that 'a multicultural agenda [...] crowds out redistributive issues from the policy agenda, corrodes trust among vulnerable groups who would otherwise coalesce in a pro-redistribution lobby, or misdiagnoses the real problems facing minorities, leading them to believe that their problems lie in cultural misunderstandings rather than economic barriers that they confront along with vulnerable members of many other cultural groups' (Banting, 2005, p. 8). On the possibility of such a trade-off, see for instance Gitlin (1996), Goodhart (2006), and the debate in Van Parijs (2004). To test whether there is evidence for such a trade-off, Banting and Kymlicka construct an index of multicultural policies and classify the countries of the OECD into three groups of strong (Australia and Canada), modest (e.g., the United States and the United Kingdom), or weak policies (e.g., France, Germany). For each group, they calculate the average change in social expenditure between 1980 and 1998 (from OECD data) and the average change in the redistributive impact of taxes and transfers between the early 1980s and late 1990s (from the Luxemburg Income Study). A cross-tabulation shows no evidence of a negative relationship between multicultural policies and the change in social spending and redistribution (Banting and Kymlicka, 2004), and this finding is confirmed in a multivariate analysis (Banting et al., 2007).

These cross-country studies have been criticized for a number of reasons. A first criticism concerns general issues of measurement and of comparability across countries. For instance, in his discussion of Alesina et al. (2001), Durlauf (2001) points to a possible measurement problem in the dependent variable. He argues that their dependent variable (social spending over GDP) underestimates the true amount of welfare spending in the United States, since both the Earned Income Tax Credit and the costs of affirmative action programs should be included under welfare spending.

The measurement of ethnic diversity has sparked even more criticism. Most of the early crosscountry studies measure ethnic diversity by the indicator of ethno-linguistic fractionalization (ELF) from the Atlas Narodov Mira (Bruk and Apenchenko, 1964). The ethnologists who compiled the data in the early 1960s relied mostly on language to delimit ethnic groups. ELF gives the probability that, at the time when the data were collected, two individuals drawn at random from the population belong to different linguistic groups.

Journal of Economic Surveys (2013) Vol. 27, No. 2, pp. 364-389

(C) 2011 Blackwell Publishing Ltd 
Chandra (2001), Laitin and Posner (2001) and Posner (2002, 2004a,b) criticize the use of this variable in the cross-country growth literature for two reasons. First, most studies use data on ethnolinguistic groups from the early 1960s to test hypotheses about the consequences of ethnic diversity in much later periods; that is, the studies assume, sometimes implicitly, that ethnic diversity does not change or changes slowly. This assumption is questionable. Migration and different rates of fertility and mortality may have changed the ethnic make-up of the population since the early 1960s. Moreover, most sociologists and anthropologists now agree that ethnic identity (and, by implication, ethnic diversity) is socially constructed and may change over time. In fact, causality may run from the dependent variable such as the growth of GDP per head to the degree of ethnic diversity, and third factors such as political stability that are not always controlled for in the studies may influence both ethnic diversity and the growth of GDP. ${ }^{3}$ One mechanism may be that in countries which are politically unstable or grow slowly, ethnic diversity increases as people fall back on their ethnic groups. The possible endogeneity of many regressors is of course a general problem in cross-country studies on growth and in observational studies more generally.

Laitin and Posner (2001)'s second criticism is that ethnic identity has more than one dimension and that an exclusive focus on ethno-linguistic groups is therefore misleading: the salient dimension of ethnicity may not be language but some other cultural trait or the phenotype (e.g., skin colour). In other words, even if ethnic identity were static, the data set would be ill-suited to test the hypotheses of the empirical studies.

Another criticism concerns not so much the classification of ethnic groups but the relevant measure of diversity. Collier (2001) argues that a single index of fractionalization misses some important dimensions. In particular, he calls for a distinction between ethnic fragmentation and ethnic dominance, since political economy models suggest that the two do not have the same effect on policies and on growth. Arcand et al. (2000) also argue that polarization may be more important than fractionalization.

In reaction to these criticisms, new data sets have been constructed by Annett (2001), Yeoh (2001), Posner (2002, 2004b), Alesina et al. (2003), Fearon (2003) and Selway (2011). These studies capture more dimensions of ethnicity than just language and try to better identify the salient ethnic cleavages in each country. Reynal-Querol (2002); Montalvo and Reynal-Querol (2005b,a)) propose an index of ethnic polarization; Bossert et al. (2006) develop a generalized index of fractionalization that takes into account similarities (for instance, with respect to income or education) among individuals. ${ }^{4}$

Finally, Vigdor (2002) and Rushton (2008) argue that studies using ethnic diversity as a regressor should better justify why they believe that it is only diversity that matters, and not the share of the groups. Rushton also points out that it is often of interest which groups are represented and in which proportions. The index of fractionalization has the same value regardless of whether $30 \%$ of the population are black and the remaining $70 \%$ white, or if it is the other way around, but Rushton argues that in the context of the United States which group is in the majority may well make a difference.

\subsection{Studies at the Subnational Level}

Ethnic diversity has also been found to be associated with differences in public spending at the subnational level; so far, these studies have relied almost exclusively on data from the United States. Exploiting within-country variation offers the advantages of better data quality and of greater comparability of jurisdictions, mitigating the risk of bias from omitted variables. Finally, these data allow a better distinction of different types of public spending and redistribution, some of which have a strong public good character, while others can be targeted at specific groups.

However, many spending decisions are made at a local level, and 'state average spending levels therefore conceal substantial heterogeneity within states' (Poterba, 1997, p. 52); in other words, there 
is not always an 'exact match between the unit of observation and the relevant jurisdiction for voting on the public good' (Alesina et al., 1999, pp. 1255-1256). In these cases, it is unclear how to interpret the observed correlations. Studies typically deal with this problem by running regressions at different geographical levels. Another potentially serious problem is that the demographic composition of a jurisdiction is likely to be endogenous: it is affected by decisions on public spending (reverse causality) and possibly correlated with unobserved influences on public spending (omitted variables bias). This also holds true at the country-level, but the endogeneity bias is likely to be exacerbated at more disaggregated geographical levels where the level of mobility is higher.

With these caveats in mind, the three main results from the studies using variation in ethnic diversity within the United States are as follows: First, the relationship between ethnic diversity and the overall level of public spending is ambiguous. Cutler et al. (1993) show that the relationship is positive at the county level and negative at the state level. They argue that the difference can be explained by the fact that public spending at the state level is of a different kind than at the county level. In particular, the share of spending for social services and for income maintenance is much higher at the state level. Additionally, Cutler et al. explore the hypothesis that measuring variables at the county level may be misleading if the surroundings of the county have an influence on spending decisions. Evidence supporting this hypothesis comes from regressions in which state-level variables are entered into the county-level models. Cutler et al. find that a higher share of non-whites at the state level lowers public spending per capita at the county level.

Second, for a given level of public spending, ethnic diversity seems to lead to a shift from public spending on public goods to the public provision of private goods, arguably because the latter can be targeted to particular ethnic groups. In two related papers, Alesina et al. (1999, 2000) show evidence that greater racial fractionalization in a jurisdiction is associated with less spending on public (nonexcludable, non-rival) goods. By contrast, in ethnically diverse jurisdictions more tends to be spent on the public provision of private goods, from which particular groups can be excluded. Also, and consistent with the authors' argument of 'ethnic patronage,' public employment tends to be higher in ethnically diverse jurisdictions. The authors argue that more is spent on private goods because 'each ethnic group's utility level for a given public good is reduced if other groups also use it' (Alesina et al., 1999, p. 1244). Also, in an ethnically diverse jurisdiction preferences on which public goods are to be financed tend to be more heterogenous, which, according to Alesina et al., makes it more difficult to reach an agreement.

In two recent studies, Hopkins $(2009,2011 \mathrm{a})$ ) comes to different conclusions, though. Based on panel data on communities in Massachussetts and Texas, he argues that it is not so much the level but rather the increase in ethnic diversity that reduces the provision of public goods (Hopkins, 2009). He distinguishes day-to-day services from long-term projects and finds that it is mainly the latter that are reduced when the ethnic make-up of a community is subject to sudden changes. According to Hopkins, this pattern results because the increase in diversity changes people's expectations about how long they will stay in the community. ${ }^{5}$

In a second study, Hopkins (2011a) takes a new look at the relationship between ethnic diversity and public spending in U.S. cities. Using data for the period 1950-2002, he argues that the negative conclusion by Alesina et al. (1999) needs to be qualified. Hopkins finds that throughout the whole period, ethnic diversity tends to be associated with higher criminal justice spending, but is not robustly related to other components of public spending across cities. An impact on these other forms of local spending can be detected only in the 1950s and 1960s, but even then this impact is rather weak. Hopkins concludes that results from cross-sections cannot be generalized over longer periods, during which both the meaning of ethnic diversity and attitudes towards particular groups have changed: after decades of immigration from Latin America and Asia, the United States is now much more multi-racial and multi-ethnic than in the 1950s; also, racial attitudes have changed, and public expressions of racism have become less acceptable and less frequent. 
At the state level, a number of studies do find evidence that ethnic diversity is related to public spending. An area that has received particular attention is spending on public education. James (1987) shows that across U.S. states the percentage of blacks in the population is correlated with the percentage of private schools. Goldin and Katz (1999) study the rapid rise public secondary education in the United States between 1910 and 1940. Among other things, they show that this 'high school movement' was stronger the more homogenous a community was in terms of ethnicity, religion and income. Using panel data on U.S. states for the period 1961-1991, Poterba (1997) finds that public-school spending per pupil tends to be lower the greater the share of people aged 65 or older in a state's population. ${ }^{6}$ This negative relationship is stronger 'in states with a substantial population of older individuals who are from a different ethnic or racial group than the school-aged population' (Poterba, 1998, p. 317). As for the size of the association, 'a 1 percentage point increase in the share of nonwhites in the 0 to 17 population, holding the share of nonwhites in the 65 and over population constant, reduces the $\log$ of per-child school spending by -0.006 , or approximately one-half of 1 percent.' (Poterba, 1997, p. 60). However, Poterba bases this calculation on a point estimate that is not statistically significant at convential levels. Moreover, as he himself points out, the point estimate becomes smaller (and even less significant) once the percentage of the population living in urban areas or below the poverty line are included.

Finally, greater ethnic diversity has been found to be associated with less generous Aid to Family with Dependent Children (AFDC), the main program of social assistance until the mid-1990s. There is considerable variation in the level of these benefits: Alesina and Glaeser (2004, p. 147) report that in 1990, the state of Alaska paid over $\$ 800$ dollars per family per month, whereas the maximum benefit in Alabama and Mississippi was less than \$150. Alesina et al. (2001, p. 235) point out that in 1990, the raw correlation between the maximum level of AFDC benefits and the percentage of blacks in a state was around -0.5 . Of course, there are variables that are correlated with the share of blacks and that have an independent influence on the level of AFDC spending, the income level being a prominent example. Alesina et al. (2001) therefore control for median income in the state and find that even after controlling for income, 'a 1 percentage point change in the share of the population that is black reduces the maximum monthly AFDC payment by $\$ 6.92$ ' (p. 236). In a more detailed study that includes more control variables and also state fixed effects, Ribar and Wilhelm (1999) also find that the share of African Americans in a state is negatively associated with AFDC levels; they use data for the period 1982-1992 and even from 1969 onwards in some models. From their table 2 on page 101, one can calculate the magnitude of the association. In their preferred specification, an increase of 1 percentage point in the share of African Americans (the mean share was around $9 \%$ in the period of study) is associated with average monthly AFDC benefits that are around $9 \%$ lower. The estimated coefficient is highly statistically significant. This estimate is for AFDC benefits for a family of four with no other income; for other measures of the generosity of AFDC or welfare spending more generally, the coefficients are considerably lower and not always statistically significant.

Lind (2007) constructs a panel of U.S. states for six years between 1969 and 2000 (mostly from the 1990s). Using data from the Luxembourg Income Study, he calculates for each state a measure of the overall income inequality (before taxes and transfers), and then decomposes this overall measure into inequality between and within racial groups. Lind shows that income inequality between racial groups tends to reduce welfare spending by the state, whereas income inequality within groups increases it. These results are consistent with the predictions from his model; that is, with the median-voter model by Meltzer and Richard (1981) extended to include social preferences with higher weights for members of one's own racial group. Since inequality may be endogenous in these regressions, Lind instruments current inequality by lagged values and finds that the results change little, but he admits some doubt as to the validity of the instruments. Closer to the studies above, Lind finds that racial fractionalization is negatively related to welfare spending. However, he finds that the association 'is not very strong and 
it is not robust to the introduction of state fixed effects. As fractionalization changes little over time, this is not surprising' (p. 68).

In one of the few studies at the subnational level which uses data from outside the United States, Gerdes (2011) investigates how the share of immigrants from non-Western states affected publicly provided social services and two measures of income tax payments in Danish municipalities between 1995 and 2001, a period over which a large number of refugees came to Denmark. This inflow was accompanied by a state-sponsored placement policy. Refugees were free to relocate after the initial assignment, but were given some incentives to stay. Gerdes argues that conditional on a number of covariates, the placement policy led to exogenous variation in the share of immigrants across municipalities. Gerdes finds no evidence that immigration leads to a decline in the public sector. Income tax payments are even slightly higher in municipalities with a larger share of immigrants.

\section{Individual Attitudes and Behaviour}

In the previous section we have reviewed the evidence concerning the association between ethnic diversity and public spending.

One mechanism through which ethnic diversity is thought to affect public spending is through individuals' preferences. If citizens are more supportive of redistribution when people from their own ethnic group benefit from it, ethnic diversity will reduce the support for redistribution, which in turn will tend to decrease the actual level of redistribution. ${ }^{7}$ Similar arguments can be constructed for other types of public spending, such as spending on education. ${ }^{8}$

To shed some light on the forces behind the aggregate relationship, a second strand of the empirical literature has used data on individual attitudes and behaviour. Most of the studies use observational data from surveys (Section 3.1); more recently, the effect of ethnic diversity on attitudes and behaviour has also been studied in experiments (Section 3.2).

\subsection{Observational Studies}

The observational strand of the literature can be further subdivided into studies that focus on the effect of ethnic diversity on social capital, and studies that directly measure the effect on the (self-reported) support for the welfare state.

\subsubsection{Social Capital}

During the 1990s, social scientists have become increasingly interested in social capital and, in particular, in trust. Trust facilitates economic transactions in a world in which not all eventualities can be dealt with through formal contracts. Both trust and social capital in general also matter for the welfare state. First, volunteer activities and charity spending are a substitute for government-run social policy. Second, social insurance programs are subject to moral hazard problems and, say, generous unemployment insurance is politically most feasible in countries where people generally trust each other to not take undue advantage of the system (see, e.g. Algan and Cahuc, 2009).

Cross-country studies, such as the one by Knack and Keefer (1997), show a positive correlation between the average level of trust in a country and the country's economic performance. Furthermore, it has been remarked that countries with high average levels of trust, such as the Nordic countries, tend to have homogenous populations. In this subsection, we focus on observational studies that test whether there is such a link between ethnic diversity and trust within countries. The effect of ethnic diversity on trust has also been studied in experiments. We will come back to these studies in subsection 3.2 below. 
Using individual-level data from the U.S. General Social Survey for the years 1974-1994, Alesina and La Ferrara (2000) regress (self-reported) participation 'in a variety of social activities including recreational, religious, civic, and educational groups' (p. 850) on individual and community characteristics (at the level of metropolitan sampling areas and primary metropolitan sampling areas). Ethnic and racial fractionalization, the variables of interest, are calculated from the 1990 Census; this value is used for the whole period. ${ }^{9}$ In probit models, which include state- and time- fixed effects, Alesina and La Ferrara 'find that, after controlling for many individual characteristics, participation in social activities is significantly lower in more unequal [in terms of income] and in more racially or ethnically fragmented localities.' (p. 847). The negative association is rather strong: an increase of one standard deviation in a community's racial fractionalization is associated with a probability of participating that is lower by eight percentage points. This is twice as large as the reduction in the participation probability associated with having a child below the age of five. The negative partial correlation is strongest for groups in which interaction is typically more frequent (youth clubs and churches, as opposed to, say, professional associations). Finally, Alesina and La Ferrara find 'that those individuals who express views against racial mixing are less prone to participate in groups the more racially heterogeneous their community is' (p. 847). However, the study cannot identify to what degree the lack of participation is caused by racial attitudes, and to what degree it is the other way around.

In a related study and using the same data from the General Social Survey, Alesina and La Ferrara (2002) find that the probability that respondents declare that 'most people can be trusted' is lower in more racially heterogenous communities. They also find that income inequality in a community is negatively related with interpersonal trust. By contrast, they do not find a significant association between trust and ethnic (as opposed to racial) diversity. 'The magnitude of the coefficient on racial fragmentation is substantial. Moving from the most homogeneous MSA where racial fragmentation assumes the value of 0.06 to the most heterogeneous where it is 0.61 , the likelihood of trusting others would fall by 12 percentage points, i.e. about 30 percent of the mean. Starting from the sample mean, an increase by one standard deviation in racial fragmentation decreases the probability of trusting others by 3 percentage points, i.e. almost 10 percent of the mean value. This is larger than the effect of having had a traumatic experience in the last year, and almost the same size as the effect of being divorced or separated' (p. 222). Interestingly, Alesina and La Ferrara find that only trust in other people is lower in more racially heterogeneous communities, not trust in institutions. As in their 2000 article, they find that the negative association is strongest for people who declare themselves to be against racial integration.

Costa and Kahn (2003) show additional evidence on the links between ethnic diversity and social capital in the United States. They measure social capital using information from several data sets on volunteer activity, organizational membership and activity, and entertaining and visits with friends, relatives, and neighbours. In a pooled cross-section with year-specific intercepts, and at the level of metropolitan areas, they find significant negative association with ethnic diversity only for the probability of volunteering (DDB Lifestyle Survey, 1975-1998) and for membership in non-church organizations (American National Election Survey, ANES, 1952-1972). As for the size of the association, "the increase of 0.092 in the racial fragmentation index from 1950 to 1970 predicts a decline in nonchurch group membership in the ANES of 0.04." (p. 105). Interestingly, even though they use the same data from the General Social Survey as Alesina and La Ferrara, they do not arrive at the same results. Costa and Kahn find a positive (but insignificant) relationship between racial fractionalization and the probability of being a member of an organization; as for trust, they do find a negative point estimate, but the estimated coefficient is not statistically significant. Finally, Costa and Kahn study whether changes in ethnic diversity can predict changes in social capital in the period between 1952 and 1998. They find that the increase in community heterogeneity can predict between 6 and 13 percent of the decline in social capital from the mid-1970s to the end of the 1980s (or the 
end of the 1990s in some models). Much more of the decline can be predicted by the increase in wage inequality.

In two recent studies, Hungerman $(2008,2009)$ examines the link between ethnic diversity and charitable activity by church congregations in the United States. In a first article, Hungerman (2008) finds that all-white congregations tend to be less active (relative to congregations that are not allwhite) in communities with a higher share of blacks in the population. Hungerman acknowledges the possibility of omitted variables bias (e.g. white congregations in black communities may be poorer on average), but his results survive a number of robustness checks: he controls for the income of the congregation members, includes community fixed effects, and instruments the current share of blacks in the community by the lagged share. Moreover, it is only charitable activity that tends to be lower in communities with a higher share of blacks; other spending by the congregations is if anything higher.

In a second study on charitable church activity, Hungerman (2009) studies how the crowding-out of private charity by government spending differs by the ethnic diversity of the community. He uses the natural experiment of an expansion of a federal welfare program (Supplemental Security Income, SSI) mandated by the U.S. Supreme Court in 1991. His outcome variable is charitable activity by the United Methodist church for the years 1984-2000. Hungerman confirms that government spending crowds out charitable activity, but he finds that this average effect is driven almost exclusively by ethnically homogenous communities. In ethnically diverse communities, by contrast, there is only a modest effect, which suggests that charity in diverse communities is driven more by 'warm glow' motive (pleasure derived from the act of giving per se) than by pure altruism.

\subsubsection{Attitudes Towards the Welfare State}

A number of other studies have examined the effect of ethnic diversity on people's support for the welfare state, based on answers to survey questions.

A methodological point on studying individual attitudes may be in order. What is observed in these studies are self-reported answers to survey questions about trust or the welfare state. While it is straightforward to estimate how these self-reported answers covary with other variables of interest such as ethnic diversity in a respondent's region, the ultimate interest is not to study respondents' answers to survey questions, but rather their true attitudes towards the welfare state. The true attitude is unobserved, however, and so statements about it have to rely on untestable identifying assumptions. If additional data are available, cross-validation can be used to justify these assumptions; in the literature on the determinants of life satisfaction, such cross-validation has relied on asking other people to independently judge a person's life satisfaction, or on physiological and neurological evidence. This cross-validation has increased people's confidence that something meaningful is estimated when using 'subjective variables,' at least for the literature studying life satisfaction (see the survey by Senik, 2005).

The earliest studies on the effect of ethnic diversity on attitudes towards the welfare state use data from the United States, mostly from the General Social Survey. More recently, the scope of countries covered has widened.

United States Using data from the 1986 National Election Study, the 1994 General Social Survey, and the 1991 National Race and Politics Study, Gilens (1995, 1996, 1999) shows that racial stereotypes are important predictors of the support for welfare spending among white Americans. ${ }^{10}$ Moreover, Gilens (1999) documents that black people are overrepresented in the media coverage of poverty, and particularly in the least sympathetic stories. Consistent with this overrepresentation in the media, white Americans tend to overestimate the proportion of poor people who are black.

With data from the General Social Survey for the period 1972-1993, Luttmer (2001) shows that in the U.S. people are more likely to express support for welfare spending if they live in a neighbourhood 
where the share of people of their own race among welfare recipients is high. This is true whatever the economic situation of the respondents, even among wealthy people who have only a very small risk of being welfare recipients themselves. Luttmer therefore interprets this relationship as evidence for group loyalty, that is, of solidarity being stronger towards members of one's own ethnic group than towards members of other ethnic groups. He links his results to the findings on aggregate public spending: 'I find that over 30 percent of the variation in levels of welfare benefits across states can be explained by applying my estimates of interpersonal preferences to the differences in the demographic composition of states. Hence, interpersonal preferences seem to transform difference in racial composition into differences in redistribution within the United States' (Luttmer, 2001, p. 502).

In their study discussed at greater length above, Alesina et al. (2001) have a short section on individual attitudes as well; like Gilens and Luttmer, they use data from the General Social Survey. Alesina et al. find that blacks are more supportive of welfare spending. For whites, they confirm Gilens' findings that racial attitudes are correlated with support for welfare spending: whites who believe that blacks are lazy tend to be less supportive, and whites who have had a black person over for dinner tend to be more supportive of welfare spending. By contrast, support among whites is not significantly associated with the share of blacks in the population of the respondent's state. This difference with Luttmer's results may be due to the fact that Luttmer looks at shares of blacks among welfare recipients and not in the population as a whole.

Lind (2007), whose study has already been reviewed above in the section on aggregate outcomes, also shows evidence from the General Social Survey. For the period 1972-2002 he confirms that blacks tend to be much more supportive of welfare spending than whites, even controlling for a number of observable characteristics. He also confirms that white respondents who do not mind having or actually have had an African American at home tend to be more supportive of welfare spending. On a shorter sample from 1996 to 2002, Lind shows that blacks who feel closer to blacks tend to be more supportive, and blacks who feel closer to whites less supportive of welfare spending. For whites the interaction terms have the expected (opposite) signs, but are insignificant.

Keely and Tan (2008) use classification and regression trees to detect homogenous subgroups with respect to attitudes towards welfare spending and income redistribution. These exploratory techniques are a useful complement to the models reviewed so far, which focus on the testing of hypotheses and typically assume away the problem of model uncertainty (that is, they explore at best a few interactions in an ad-hoc fashion; see the critique by Brock and Durlauf (2000) mentioned above in the context of studies on aggregate spending). Applying these techniques on data from the General Social Survey for the period 1978-2000, Keely and Tan confirm that the race of the respondent is important for classifying people with respect to attitudes towards the welfare state.

Canada Contrary to Luttmer (2001)'s result for the United States, Soroka et al. (2004) find for Canada that 'the link [between regional ethnic diversity and support for social programs] is weak at best' (p. 50); 'moving from 100\% majority to 50\% majority leads to a decrease in aggregate support for unemployment and welfare of about .0025\%' (p. 51). Their data are from the first wave of the Canadian 'Equality, Security, and Community' Study; regional demographic data are from the 1996 Canadian Census, and ethnic diversity is measured at the level of census tracts or census subdivisons. They measure support for the welfare state in three domains: employment insurance and welfare, health, and pensions. As noted, ethnic diversity in the respondent's region is not correlated with support for the welfare state in any of these three domains. By contrast, Soroka et al. confirm the finding of Alesina and La Ferrara (2002) that members of the ethnic majority tend to report less trust in other people (here measured by a question on how likely it would be to get back a wallet lost in the neighbourhood) the greater the share of ethnic minorities in their region. As in Alesina and La Ferrara's study, trust in government institutions is found to be unrelated to ethnic diversity. 
Europe Senik et al. (2009) use survey data for 22 European countries from the 2002/2003 round of the European Social Survey to investigate the link between immigration and support for the welfare state. They want to find out (1) how the perceived presence of immigrants is related to natives' support for the welfare state, and how this relationship varies (2) with natives' attitudes towards immigrants and (3) across countries. The specificity of the study lies in its emphasis on parameter heterogeneity and in the use of European instead of United States or Canadian data.

Their main result is that, for Europe as a whole, the association between the perceived presence of immigrants and natives' support for the welfare state is weak at best. They do find some evidence that natives who perceive the share of immigrants in the population to be high tend to be less supportive of the welfare state. But the association is very weak and not even statistically significant for two of their three dependent variables. An increase in the perceived share of immigrants of one standard deviation (about 16 percentage points) is associated with a decrease in the probability of supporting the welfare state of about one percentage point. This is small compared with the associations that they find for other covariates such as income or education.

However, although they find only weak evidence for a negative association between immigration and natives' support for the welfare state in general, it may well be that a negative association does exist for certain sub-groups of natives. In a second step they therefore interact the variables measuring the actual or perceived presence of immigrants with variables measuring natives' attitudes towards immigrants. Exploring this parameter heterogeneity is made possible by the rich set of such attitudinal variables in the European Social Survey.

As expected, Senik et al. (2009) find that the association between the perceived share of immigrants and support for the welfare state is most negative for natives who both dislike immigrants and express concern about the economic consequences of immigration. By contrast, the association is positive for those natives who regard immigration as positive along both dimensions. There is no clear evidence concerning the relative importance of the two channels: often, the parameter estimates for the two intermediate types are not significantly different from each other.

When Senik et al. (2009) include the two channels also as main effects (instead of interacting them with the perceived share of immigrants), they find that attitudes towards immigration and attitudes towards the welfare state are strongly associated, but that this association is little affected by the (perceived) presence of immigrants.

A third contribution of their article is to look at differences across countries within Europe. They find that the small average effect masks considerable heterogeneity across countries. However, the general result is preserved: the practical significance of the association between the perceived presence of immigrants and natives' support for the welfare state is small even in the countries for which the estimated coefficients are largest.

Based on the same data from the first round of the European Social Survey, Finseraas (2008) studies the relationship between attitudes towards immigration and attitudes towards income redistribution. Unlike Senik et al. (2009), Finseraas does not include the perceived share of immigrants in his main model. However, he adds an interesting aspect by pointing out that in addition to the anti-solidarity effect (which should reduce the preferred level of redistribution), there may be a 'compensation effect': if immigration increases the (perceived) risk of income loss, the preferred level of redistribution could increase as the share of immigrants rises. Finseraas finds some evidence of both effects. Moreover, he shows that the antisolidarity effect is stronger in countries with a Social Democratic welfare state regime (where social transfers tend to be universal and tax-financed), whereas the compensation effect is stronger in Conservative welfare states (where transfers tend to be based on previous contributions).

Germany Using data from the 1997 and 2002 waves of the German Socio-Economic Panel and from official statistics, Stichnoth (2011) studies whether natives are less supportive of state help for the 
unemployed in regions where the share of foreigners among the unemployed is high. The models are estimated using individual-level panel data, which allows more convincing identification of a causal effect. This is an advantage over previous studies that had relied on (repeated) cross-sections. (The recent study by Dahlberg et al. (2011), summarized below, also uses individual-level panel data, and has the additional advantage of exploiting exogenous variation stemming from a refugee-placement program.)

The main result is that there is at best weak evidence that German natives' support for the unemployed is influenced by the regional share of foreigners among the unemployed. Mean comparisons show that people in areas with a high share of foreigners among the unemployed do tend to be less supportive of state help for the unemployed. However, much of this difference is driven by common influences such as income or East German origin. Once these individual characteristics are controlled for, the share of foreigners among the unemployed is still negatively associated with natives' support for the unemployed, but the association is rather weak compared to other variables such as income, selfemployment, or East German origin. Stichnoth (2011) finds that a one standard deviation increase in the share of foreigners among the unemployed is associated with a reduction in the support for financial help to the unemployed of about two percent of the standard deviation of the dependent variable.

Scandinavia Eger (2010) studies how variation in the share of immigrants and foreigners across 21 Swedish 'län' ('Sweden's first level administrative and political subdivision', p. 6) is related to support for public social spending. Eger pools cross-sectional data from opinion polls for the years 1986, 1992, 1997, and 2002, and merges them with regional level census data. She finds that three different measures of immigration (percent recent immigrants, percent foreign citizens, percent foreignborn) are negatively related to an index of attitudes towards social spending. However, when she restricts the index to items that are 'universal in nature' (p. 6) - health care, elder care, and primary and secondary school expenditure - the negative association is found only for one of three measures of immigration, namely the percentage of those who immigrated in the calendar year of the survey.

Two recent articles have exploited the regional variation in ethnic diversity that results from refugee placement programs in Denmark and Sweden. As far as observational studies go, these articles are currently the best attempts at identifying the causal effect of ethnic diversity on individual attitudes and behaviour.

Gerdes and Wadensjö (2008) study how the share of immigrants from non-Western countries in Danish municipalities affected voting behaviour in several local and national elections over the period 1989-2001. They exploit the natural experiment of a refugee placement program, which offers exogenous variation in the immigrant share. Gerdes and Wadensjö do find evidence that antiimmigration parties tend to receive more votes in municipalities with a higher share of non-Western immigrants. However, a party on the left that is both pro-immigration and pro-welfare state also tends to win votes, and the position of the (pro-welfare) Social Democratic Party is largely unaffected by the share of immigrants. The authors therefore conclude that there is 'no clear indication of a general decline in support for the welfare state on account of immigration, as several scholars have been predicting' (p. 23).

Dahlberg et al. (2011) exploit the natural experiment of a refugee placement program in Sweden. ${ }^{11}$ They merge the information on the inflow of refugees with panel survey data. The period of study are the years from 1985 to 1994; the regional variation in the immigrant share is measured at the level of 288 Swedish municipalities. ${ }^{12}$ The main result of the study is that a larger share of immigrants from non-OECD countries and from Turkey in a municipality reduces the preferred social benefit level of native Swedes. In addition, Dahlberg et al. (2011) study the effect across different parts of the income distribution. They find that the negative effect is strongest for people with high income and wealth. 


\subsection{Experiments}

The studies using survey data reviewed in the preceding section exploit regional variation in ethnic diversity and study whether respondents are more or less supportive of the welfare state in regions with greater ethnic diversity. Ethnic diversity is measured either in the population as a whole, or in some sub-group such as the recipients of AFDC transfers (Luttmer, 2001) or the registered unemployed (Stichnoth, 2011). Many observers have noted that these regional shares are unlikely to be exogenous, which means that most studies document associations instead of identifying the causal effect of ethnic diversity.

This state of affairs has changed only recently: Stichnoth (2011) uses individual panel data to exploit only temporal (that is, within-individual) variation, and the studies by Gerdes (2011) and Gerdes and Wadensjö (2008) rely on the natural experiment offered by refugee placement programs. Dahlberg et al. (2011) combine both advantages.

In addition, and as a reaction to the general limitations of observational studies, the effects of ethnic diversity on trust and on altruism have been increasingly studied in controlled experiments in the last few years, mainly in trust, ultimatum, and dictator games. ${ }^{13}$ In addition, there have been a number of interesting field experiments that study ethnic or racial discrimination on the labor market based on fictitious job applications (Bertrand and Mullainathan, 2004; Carlsson and Rooth, 2007). With its focus on the labor market, this literature is beyond the scope of this survey. The same holds for the older literature of 'audit studies' or 'situation tests', in which comparable actors, but of different ethnic or racial background, are placed into actual economic or social settings. The studies by Bertrand and Mullainathan and by Carlsson and Rooth discuss the strengths and weaknesses of these 'situation tests' and provide further references.

Experiments offer the advantage that the experimenter can create exogenous variation in the experimental conditions through randomization; as a result, experiments are the gold standard for the identification of causal effects. A second, related advantage is that because of this control of the experimental conditions, experiments can be used to explore the channels through which an effect operates. In the case of ethnic diversity, experiments can shed some light on whether people behave differently towards members of another ethnic group because of preference-based or statistical discrimination. Third, experiments allow the observation of behaviour, as opposed to self-reported attitudes in a survey. These reasons explain why experiments have become increasingly popular in the literature on the effects of ethnic diversity on support for redistribution.

However, a major drawback of experiments is the loss of external validity: because the subjects are often a non-random sample of some specific population (typically, undergraduate students), and because their behaviour is observed in the artificial setting of the experiment, it is unclear to what extent the results can be generalized. This is particularly true for laboratory (as opposed to field) experiments. See Levitt and List (2007) for an elaboration on these points, and Falk and Heckman (2009) for a defense of laboratory experiments.

In this section we briefly review this very active strand of the literature. We focus on experiments in economics and leave aside the much older and larger literature in social psychology on the effects that group affiliation in general and race and ethnicity in particular have on individual behaviour (see, e.g. Brown, 2000, 2010). Moreover, we review only experiments on the effects of inter-ethnic relations and not on comparisons between groups of different but more or less homogenous cultural or ethnic backgrounds. A well-known study of this second type is by Henrich et al. (2001), who study behaviour in games in fifteen ethnic groups around the world. Furthermore, we focus not on groups in general, but on ethnic groups. ${ }^{14}$ Because of this focus on ethnic relations we do not report results on whether particular ethnic or racial groups are generally more or less trusting or altruistic in these games (e.g. Eckel and Grossman, 2001); what we are interested in is whether people condition their strategies on the (supposed) ethnic identity of the other player. 
Given these selection criteria, the experimental literature on the effects of ethnic group affiliation begins with a study by Glaeser et al. (2000). They show that in a trust game played with Harvard undergraduates the recipient returns more when he or she is of the same race or nationality as the sender. By contrast, the amount sent does not differ by the race or nationality of the recipient.

Fershtman and Gneezy (2001) use a series of experiments to study trust and altruism between Ashkenazi and non-Ashkenazi Jews in Israel (the latter group tends to fare less well in economic and social terms). The study is interesting because it uses different games to shed some light on whether the behaviour towards a particular group is driven by statistical or by preference-based discrimination. The experiment is conducted with university students, and group affiliation is inferred by the surname of the players (the players do not actually meet).

Fershtman and Gneezy find that non-Ashkenazi Jews receive smaller amounts of money in a trust game. However, two pieces of evidence suggest that this discrimination does not seem to be based on preferences: first, even non-Ashkenazi Jews themselves tend to send less money when the receiver is a non-Ashkenazi Jew. Second, in a dictator game, there is no evidence that non-Ashkenazi Jews are discriminated against. Fershtman and Gneezy therefore conclude that the smaller amounts sent in the trust game reflect statistical discrimination - which, in the experiment, is based on mistaken beliefs, for non-Ashkenazi Jews are found to be no less trustworthy than Ashkenazi Jews: the amount that the receiver returns is not significantly different between the two groups.

Finally, the study confirms that gender matters for trust and altruism. More to our point, the importance of group affiliation also differs by gender. Fershtman and Gneezy find that there is no statistically significant evidence of discrimination in the trust game when the receiver is a woman. Moreover, women did not discriminate between Ashkenazic and non-Ashkenazi male players.

In a trust game with small businessmen of Belgian and Turkish ethnic origin in the city of Ghent in Belgium, Bouckaert and Dhaene (2004) find that 'the average levels of trust and reciprocity are independent of ethnic origin and, moreover, independent of the ethnic origin of the opposite party' (p. 869). In their study, ethnicity is inferred from the first names of the participants. Studying small businessmen (instead of students as in the studies by Glaeser et al. and by Fershtman and Gneezy) is interesting because it helps gauge whether the previous results were specific to students or valid more generally; moreover, trust is arguably more important in their professional lives for small businessmen than for students. Bouckaert and Dhaene speculate that the absence of discrimination in their study may be due to the fact that the participants 'were equal with respect to gender, socio-professional status, and place of residence, and they knew this. [...] This leads to the tentative conclusion that ethnic discrimination between interacting parties vanishes when enough other characteristics are equal.' (p. 872).

Habyarimana et al. (2007) use a number of different games to identify the mechanisms through which ethnic group affiliation affects behaviour. They focus on the provision of public goods; observational studies have documented a negative correlation between ethnic diversity and the provision of (certain types of) such goods (see the references in the introduction). The experiments are conducted with 300 subjects in several slums of Kampala, Uganda, a city that is ethnically diverse and in which ethnicity is highly salient. Participants are drawn at random from the local population, inference from the sample to this population are possible. In some of the games, ethnic group affiliation is ascertained through face-to-face interaction; in other games, subjects are shown photos and videos.

Habyarimana et al. confirm that the degree of ethnic fragmentation of an area is negatively correlated with 'whether, during the last six months, residents of the LC1 [an administrative district in Kampala] had organized community efforts in the area of crime prevention and security' (p. 712 n. 7).

Their main finding is that this negative correlation probably results from strategic concerns: coethnics cooperate because they adhere to within-group norms and institutions that facilitate the sanctioning of individuals who fail to contribute to collective endeavors. By contrast, the link from ethnic group affiliation to the provision does not seem to pass through preferences or technology.

Journal of Economic Surveys (2013) Vol. 27, No. 2, pp. 364-389

(C) 2011 Blackwell Publishing Ltd 
Concerning preferences, they ask subjects about their priorities for public goods provision and on how these public goods should be provided. It turns out that answers do not differ significantly across ethnic groups, which (at least in this particular context) casts doubt on the assumption that public good provision is lower because ethnic groups differ in their preferences over the type of public good that should be provided - an assumption that is made by Alesina et al. (1999), for instance. The second preference-related explanation is that people are less altruistic towards members of other ethnic groups; this argument of group-specific weights in an inter-dependent utility function is formalized in Lind (2007), among others. However, consistent with the earlier findings by Fershtman and Gneezy (2001), Habyarimana et al. do not find evidence that in a dictator game people are less altruistic towards members of other ethnic groups.

Concerning technology they conclude that 'Nor are technological explanations central. Co-ethnics do not appear to cooperate with one another simply because cooperation is easier with people that share a common language or modes of interacting.' (p. 3). However, this conclusion is based on evidence from two games in which two players have to work together to open a lock or to put together a jigsaw puzzle - that is, two rather specific forms of cooperation. In any case, although a common language and strong social ties do not seem to faciliate cooperation directly, they underlie what Habyarimana et al. call the 'strategic explanation': 'co-ethnics benefit from stronger network linkages among them, linkages which make it possible for individuals to sanction co-ethnics that defect' (p. 3).

Haile et al. (2008) conduct a trust game with students of two universities in South Africa. Their contribution is to disentangle the effects of ethnicity and of income on trust. They note that in the studies by Glaeser et al. and by Fershtman and Gneezy, the group that is discriminated against (blacks in the former and non-Ashkenazi Jews in the latter case) is weaker economically, so that it is not clear whether the senders in the trust game condition their strategies on the responders' economic position or on their ethnicity. Somewhat surprisingly perhaps given the history of race relations in South Africa, Haile et al. find no evidence that either income or race by themselves affect the amounts transferred. However, there is evidence that whites with low income tend to transfer less money to high-income blacks, and that low-income blacks transfer less to high-income whites - Haile et al. term this 'cross-racial envy'. Low-income blacks do not expect lower returns from high-income whites, so in their case the conditioning of strategies appears to reflect preference-based and not statistical discrimination. Consistent with this, low-income blacks tend to return less money to high-income whites; this is the only statistically significant evidence for discrimination at the stage of the responder. As for low-income whites, they expect less reciprocity from high-income blacks, but this expectation turns out to be wrong in the experiment.

Whereas the studies reviewed so far have used one-shot versions of the trust game, Bornhorst et al. (2010) conduct repeated trust games; moreover, in their version of the trust game, senders choose the players to whom they transfer money. The subjects of the study are Ph.D. students at the European University Institute in Florence. Bornhorst et al. find evidence that participants condition their strategies on whether the other player comes from a Northern or a Southern European country. Southern Europeans tend to receive less money; more importantly, they are chosen less frequently as receivers. These differences tend to increase in the course of the game; they are mainly driven by the behaviour of Northern Europeans. Bornhorst et al. argue that Southern Europeans tend to be contacted less frequently and tend to receive less money because they exhibit lower levels of trust themselves. Since generous transfers tend to be rewarded by other generous transfers, the smaller transfers that Southern Europeans tend to make hamper the build-up of trust towards them.

Falk and Zehnder (2007) study whether people condition their strategies in a trust game on the city district that the recipient lives in. They work with about 1000 subjects, drawn at random from the population of Zurich. As a result, Falk and Zehnder have a more heterogeneous subject pool than studies working with university students; moreover, the large number of participants allows them to study the individual correlates of trust and discrimination. Falk and Zehnder find that about 55\% of 
their subjects discriminate by district, whereas $45 \%$ send the same amount to all districts. The district that receives the highest average amount receives about $11 \%$ more than the district with the lowest average amount. They find that districts with higher social status (measured by median income and share of people with at least high school education) tend to receive more. There is also evidence for in-group favouritism at the level of residential districts: controlling for other factors, people tend to send about ten percent more to recipients in their own district. Most important for the focus of this survey, Falk and Zehnder find that recipients living in districts with a higher share of foreigners tend to receive less.

In an additional experiment conducted with the help of a local newspaper, Falk and Zehnder show that people (who did not participate in the original experiment) can predict well which districts would receive the highest average amounts; this suggests that beliefs about the trustworthiness associated with certain districts (and, arguably, with socio-economic and immigration status) are widely shared among the residents of Zurich.

Interestingly, Falk and Zehnder find evidence that the discrimination is not purely preference-based. First, the amount of money invested in a district is positively correlated with the return expected from that district. Moreover, unlike in the study by Fershtman and Gneezy (2001), differences in trust are at least partly justified by actual differences in trustworthiness and are not just mistaken stereotypes.

Finally, as for the individual correlates of discrimination, Falk and Zehnder find that older people tend to discriminate more, whereas more educated people and people with children tend to discriminate less. Falk and Zehnder do not find significant differences between men and women, between foreigners and Swiss nationals, or for participants who grew up as an only child.

Fong and Luttmer (2009) study whether race affects actual charitable giving and self-reported attitudes towards private and public spending to help the victims of hurricane Katrina. They present slide shows and audio stories to 1300 respondents, roughly representative of the U.S. adult population. Through the images and the audio commentary, Fong and Luttmer manipulate respondents' perceptions of the income, deservingness, and race of victims.

Fong and Luttmer study two types of outcome variables. First, to measure how the race of the recipients affects actual behaviour in a dictator game, they ask respondents to split 100 dollars between themselves and a charity helping victims. The second type of outcome variables are answers to survey questions on whether government and charities should spend more or less helping the victims of the hurricane.

Concerning actual behaviour, Fong and Luttmer find that on average, there is no influence of race or deservingness on the amount that people give: 'in the overall sample [...] the response is $-\$ 2.2$. Thus, the point estimate suggests that there is little effect of victims' race on giving, but given that the $95 \%$ confidence interval on this estimate ranges from about $-\$ 10$ to $\$ 5$, we cannot rule out a moderately large racial bias in giving in the overall sample.' (p. 11). However, for subgroups there is evidence of a racial bias: whites who strongly identify with their own racial group tend to give less when the victims are portrayed as predominantly black; blacks who strongly identify with their own racial group tend to give more in the same treatment. Fong and Luttmer conclude that 'social identity is an important predictor of racial bias, but that race by itself is not a good proxy for social identity.' (p. 26)

As for attitudes towards public and private spending to help the victims, race and deservingness are important predictors. Unlike for actual behaviour, this holds for everybody, not just for the subgroup of people who strongly identify with their own racial group. Fong and Luttmer find that whites tend to be less supportive of helping the victims if these are portrayed as black.

To explain why race matters more for attitudes towards public assistance than for own giving to a private charity, Fong and Luttmer argue that the latter may be seen to better pre-select individuals who receive assistance: 'respondents [may] believe that Habitat for Humanity [the charity to which respondents can contribute in the dictator game] only provides assistance to deserving individuals, while government programs may not. If this is true, then there may not be enough variation in perceptions

Journal of Economic Surveys (2013) Vol. 27, No. 2, pp. 364-389

(C) 2011 Blackwell Publishing Ltd 
of deservingness of recipients in our charity experiment. This could also explain why race does not matter in our charity experiment, if racial bias is mediated by perceptions of relative deservingness of white and black recipients, as some have argued (Gilens, 1999)' (p. 3).

\section{Conclusion}

This paper has surveyed the empirical literature on the effects of ethnic diversity on natives' attitudes towards redistribution. As mentioned in the introduction, there is a growing concern about a trade-off between a generous immigration policy and a generous welfare state. For instance, in a well-known contribution Alesina and Glaeser (2004) have made the case that immigration and ethnic diversity help explain why the United States does not have a European-style welfare state. These public concerns and strong claims have motivated the writing of this survey.

However, our main conclusion from this survey is that the evidence is mixed at best. In some studies, the level of ethnic diversity is unrelated to public spending or to individual attitudes and behaviour. In other studies, there is evidence of an association, but the association is weak. For instance, in many studies on individual attitudes towards redistribution or public spending, the association with ethnic diversity is much weaker than for other factors such as own income (current or expected) or beliefs about the role of effort versus luck in determining this income.

This is not to deny that many studies do show evidence of a negative association. A natural next step would be to conduct a meta-analysis in order to find out when and where ethnic diversity does seem to matter for public spending and individual support for it. Such an analysis, which could build on the present survey, could shed some light on whether differences in results are driven by differences in methods or by true differences across periods or countries. For instance, the relationship between ethnic diversity and public spending will likely depend on the welfare state regime (Finseraas, 2008) or the political system. Also, the relationship is most likely non-linear: ethnic diversity will matter most near a 'tipping point' at which ethnic minorities are perceived as posing a political or economic threat to the native majority. Such threshold and interaction effects have been discussed mostly in the cross-country literature (see, e.g. Selway, 2011), and have been absent from many of the studies at the subnational and at the individual level.

Another interesting interaction effect has been documented in two recent articles by Hopkins (2010, 2011b). He studies attitudes towards immigrants and not attitudes towards public spending, but the argument likely applies to the second case as well. Hopkins argues that the level of local ethnic diversity does not have an impact on individual attitudes towards immigration per se, but only (1) when ethnic diversity is rising and (2) when the issue of immigration is politicized at the national level. His theory can explain 'how a relatively steady stream of immigrants produces anti-immigrant actions clustered in time and space' (Hopkins, 2011b, p. 43). Hopkins supports his claim with results from a large number of surveys for the United States (Hopkins, 2010, 2011b) and from a British survey (Hopkins, 2010).

Moreover, more needs to be learnt about the causal effect of ethnic diversity on public spending and individual support for it. There is a growing body of experimental evidence on this issue, which is of course strong on internal validity but works with small and sometimes rather specific samples. The quest for causal effects has also motivated the recent quasi-experimental studies by Gerdes and Wadensjö (2008), Gerdes (2011) and Dahlberg et al. (2011). These three studies use refugee placement programs in Denmark and Sweden. Similar evidence for other countries would be most useful.

As mentioned in the introduction, the focus of the survey is not on the direct fiscal effects of ethnic diversity and immigration (within a given welfare state, for example, for a given legislation concerning welfare benefits), but on how ethnic diversity and immigration change the structure of the welfare state (e.g. shifts between different types of spending by a (hypothetically) given overall level of public spending; less generous rules concerning welfare benefits). However, empirically identifying the two 
effects is not always easy. Some studies, especially those using data at the subnational level within the United States, do try to control for the direct fiscal effect in some way. For instance, Alesina et al. (2001) control for, among other things, the median income in a state when estimating the effect of ethnic diversity on the maximum level of AFDC benefits. Poterba (1997) uses the spending per student as a dependent variable, not the overall education spending, which is also directly affected by the demographic composition of a state. Hopkins (2009) shows that an increase in ethnic diversity has the strongest negative effect on long-term investment projects in a community, and not so much on public spending on day-to-day services for which these direct effects would presumably be stronger. Also, the direct effect on public spending will be positive in many cases. The arrival of immigrants is likely to increase public spending (most directly in the case of receiving refugees), which means that a negative relationship between ethnic diversity or immigration and public spending would be an underestimate (in absolute terms) of the negative indirect effect. More should therefore be done to distinguish the direct from the indirect effect.

Another question that has not been settled concerns the channels and mechanisms that are behind the influence of ethnic diversity on individuals' support for the welfare state. Both economic concerns and pure discrimination likely play a role here. Some data sets, such as the General Social Survey (GSS) and the European Social Survey (ESS), do provide questions that allow to proxy for the two channels, and there is evidence that both matter (Alesina et al., 2001; Lind, 2007; Senik et al., 2009). However, even if the data allow to proxy for the two channels, these observational studies are plagued by the usual problem that causality is hard to establish. Experiments offer better prospects of distinguishing the causal effect of the two channels. However, as pointed out by Haile et al. (2008), in the studies by Glaeser et al. (2000) and by Fershtman and Gneezy (2001) the group that is discriminated against is weaker economically, so it is not clear whether the senders in the trust games condition their behaviour on the responders' ethnicity or on their economic position. Haile et al. show evidence on some interesting interaction effects between ethnicity and position in the income distribution. Further experiments along these lines are likely to add valuable insights.

Finally, and related to the last point, the empirical literature on the effects of ethnic diversity has only barely begun to draw on the knowledge that other disciplines offer on why ethnicity is a relevant marker for social identity (see, e.g. the critique by Green, 2004). Until about the later 1960s, the predominant view was that ethnic ties are natural and ineffaceable. This 'primordialist view' (exemplified for instance by Geertz (1963); see also Van den Berghe $(1981,1986,1995)$ for a socio-biological underpinning) has since been replaced by constructivist theories that see ethnic identities as much more fluid. While we are certainly no experts in this discussion, it seems to us that the reasons for which and the speed with which ethnic identities are constructed matter for the practical question of whether measures of ethnic diversity can safely be assumed to be exogenous in empirical emplications. The studies reviewed at the end of Section 2.1 recognize this, and in many cases this recognition has led to the construction of better data sets. However, these efforts have been mostly limited to data at the country level, although the issues raised by the social constructed nature of ethnic diversity are also relevant for the observational studies at the subnational level and the experiments reviewed in this survey. Here lies an interesting area for future research.

\section{Notes}

1. For eight countries, Alesina et al. (2001) were able to construct their variable of racial fractionalization based on national census data. For the majority of countries, they used information from Levinson (1998)'s Handbook of Ethnic Groups and from the World Directory of Minorities (Minority Rights Group, 1997). 'The index is computed as the probability of randomly drawing out of the country's population two individuals that do not belong to the same racial group' (Alesina et al., 2001, p. 253). 
2. Banting and Kymlicka (2004, p. 51) write that '[u]nfortunately, there is no consensus in the literature on how to define the term "multicultural" policies. The term has quite different connotations in different countries'. In their own definition on which their empirical work is based, they 'take the following eight policies as the most common or emblematic forms of immigrant MCPs [multicultural policies]: (1) Constitutional, legislative or parliamentary affirmation of multiculturalism, at the central and/or regional and municipal levels; (2) the adoption of multiculturalism in the school curriculum; (3) the inclusion of ethnic representation/sensitivity in the mandate of public media or media licensing; (4) exemptions from dress codes, Sunday closing legislation, etc. (either by statute or by court cases); (5) allowing dual citizenship; (6) the funding of ethnic group organization to support cultural activities; (7) the funding of bilingual education or mother-tongue instruction; (8) affirmative action for disadvantaged immigrant groups' (Banting and Kymlicka, 2004, p. 56). While this enumeration defines multicultural policies towards immigrants, similar definitions are given for such policies towards substate national groups and indigenous peoples.

3. See the references in Fedderke et al. (2008, pp. 262-63). Several theoretical contributions have modelled the choice of a social identity, with ethnic identity as an important special case. See Shayo (2009) and the references cited therein.

4. Some of these studies revisit the question of the effects of ethnic diversity based on the new data sets. Typically, the application is to economic growth, which is not the focus of this survey, so the discussion will be brief here. Posner (2004b) replicates Easterly and Levine (1997)'s influential study and finds that his new measure of 'Politically Relevant Ethnic Groups' (PREG) is more closely (negatively) related to economic growth in Africa than Easterly and Levine's original measure of ethno-linguistic fractionalization. Alesina et al. (2003) confirm and reinforce the results by Easterly and Levine with their new data. They also show that the new data work better in the empirical applications when entered as a fractionalization index, as opposed to the polarization index proposed by Reynal-Querol (2002). Reynal-Querol's index has been used in a series of studies by her and her coauthors. These studies typically focus on ethnic conflict and civil war and therefore do not directly fall into the realm of this survey. In one study (Montalvo and Reynal-Querol, 2005a) they also study economic growth and come to the opposite conclusion than Alesina et al. (2003), namely that polarization is more strongly associated with growth than fractionalization. They also find that - unlike for fractionalization - the negative relationship holds not only for ethno-linguistic fractionalization but also for religion, and that polarization, but not fractionalization, is related to several likely channels from diversity to growth (civil wars, investment, government consumption). Selway (2011)'s empirical application supports his claim that multiple dimensions of ethnic diversity should be taken into account. He shows that the association between ethnic diversity and economic growth depends on the measure of ethnic diversity. The association is positive when Selway's new measures of cross-cuttingness and cross-fractionalization are used, and positive for his measure of subgroup fractionalization. He also highlights an interaction effect: 'an increase in ethnolinguistic fractionalization will result in a decrease in economic growth, but only at low levels of cross-cuttingness and cross-fractionalization' (p. 60).

5. There is a large literature on the 'White flight' that has been observed in many cities in the United States and elsewhere. In economics, the phenomenon is important for the evaluation of the labour market impact of immigration. If natives respond to an increase in immigration by leaving an area, exploiting the variation in immigrant levels or shares across local labour markets will underestimate the true impact of immigration. This particular discussion is beyond the scope of this survey. However, the general fact that location choice is endogenous is of course highly relevant for the observational studies surveyed here. Recently, studies have increasingly turned to experimental setups or to instrumental variables approaches in order to address the issue of endogeneity. We will return to this important point in Section 3.2.

6. Note that Poterba measures spending per pupil and not per head of the state's population. The latter measure would tend to go down mechanically, since the demand for education is lower in an older population. 
7. This argument is part of a broader attempt to enrich the seminal paper by Meltzer and Richard (1981) about the political economy of redistribution. In Meltzer and Richard's median voter model, individuals' demand for redistribution is led by (static) self-interest. At least since the mid-1990s this larger literature on the determinants of individual support for redistribution has studied factors beyond narrow self-interest. In particular, the importance of expectations about future income or future dependence on transfers, and hence of social mobility, has been recognized. See for instance Piketty (1995), Ravallion and Lokshin (2000), Bénabou and Ok (2001), Corneo (2001), Corneo and Grüner (2000, 2002), Senik (2004, 2006, 2008), Alesina and La Ferrara (2005b), and the surveys by Borck (2007) and by Alesina and Giuliano (2009). A second important extension has been to take into account beliefs about the deservingness of recipients, which is in turn influenced by beliefs about the determinants of social position and about the extent of social mobility. There is by now a huge amount of evidence, both from surveys and from experiments, that considerations of fairness and reciprocity matter for individual behaviour and attitudes. (See the survey by Fong et al., 2006). Razin et al. (2002) incorporate immigration into a framework in which self-interested voters decide on the extent of income redistribution. They show that because of 'fiscal leakage' (i.e. part of the redistribution accruing to immigrants instead of natives), low-skill immigration can lead to a reduction in redistribution, although the migrants themselves '(naturally) join the pro-tax/transfer coalition' (p. 167). Böheim and Mayr (2005) and Mayr (2007) study theoretically how immigration influences public spending in a situation where this spending is both on private and on public goods. In the latter case, there is no 'fiscal leakage' by definition. Whether immigration increases or decreases public spending depends on the relative importance of public and private goods, and on whether there is an 'anti-social effect', that is, on whether natives enjoy public goods less when they share them with immigrants. Shayo (2009) develops a model of social identity and applies it to the question of redistribution. In his model, the choice between a national and a class identity is influenced by the status of groups and by the similarity between group members. Since immigrants typically have relatively low income, immigration tends to reduce similarity even more in low-income groups than in the population as a whole. As a result, low-income natives are more likely to adopt a national identity instead of a class identity, thus weakening the demand for redistribution. These lower levels of redistribution will then in turn reduce the status of low income groups (as noted, status is, next to similarity, the second major determinant of social identity), making a class identity even less attractive.

8. John Roemer and coauthors have pointed out that in addition to this preference-driven anti-solidarity effect, there may be a policy bundle effect. If two parties compete along two dimensions (immigration and redistribution), the support for redistribution may be reduced because some voters who are proredistribution but xenophobic will nonetheless choose to vote for a 'right-wing' policy bundle that combines free-market and anti-immigrant policies (Roemer, 1998; Roemer and Van der Straeten, 2005, 2006; Lee and Roemer, 2006; Roemer et al., 2007). Vernby and Finseraas (2010) and Finseraas (2009) test the mechanism using survey data. Due to space constraints, we do not review this literature here.

9. Alesina and La Ferrara (2000, p. 214) use five different categories for race (White; Black; American Indian, Eskimo, Aleutian; Asian and Pacific Islander; Other, which they argue means "Hispanic" for all practical purposes), and 35 categories for ethnic/national origin, which they regroup into 10 broader categories. Ethnic/national origin is constructed from self-reported ancestry, and is not the same as own (or parents') country of birth. All data are from the U.S. Census of 1990.

10. Welfare is understood in the narrow sense of means-tested, in-cash assistance; the biggest program of this kind was Aid to Family with Dependent Children (AFDC).

11. The same natural experiment has been used to study how ethnic enclaves affect immigrants' earnings (Edin et al. 2003) and whether there is race-to-the-bottom in the setting of welfare benefit levels (Dahlberg and Edmark, 2008).

12. More precisely, Dahlberg et al. (2011) use the share of foreigners and not of immigrants; the authors recognize that because of naturalization, the two groups do not coincide. 
13. In an ultimatum game, two players interact to divide a sum of money. The first player proposes how to split this sum, and the second player either accepts or rejects the proposal. If the second player rejects the proposal, neither player receives anything. In a dictator game, the first player receives a sum of money and can then decide on how much of this money to keep and on how much of it to pass on to the second player. The second player's role in this game is passive, that is, he or she cannot reject the proposed division of money. Finally, in a trust game the first player receives a sum of money, of which he or she can send some share to the second player. The money sent is typically increased by the experimenter, and the second player then decides on how much of this money he or she wants to send back to the first player.

14. The effects of group-affiliation per se have often been studied using Tajfel et al. (1971)'s minimal group paradigm; that is, the experimenters create otherwise meaningless groups for the purpose of the experiment, for example by random assignment. Studies of this type are numerous in social psychology; recent examples in economics are Güth et al. (2008) and Chen and Li (2009). Goette et al. (2006) use random assignment to a group that is meaningful (platoons in the Swiss army). The study by Klor and Shayo (2010), again based on the minimal group paradigm, is particularly relevant for this survey's focus on public spending because subjects decide on a simple redistributive tax and transfer system. The authors show that even in such 'weak' groups, people are willing to sacrifice own monetary pay-offs to benefit the average member of their group. The experiment is inspired by the theoretical framework of Shayo (2009).

\section{References}

Alesina, A., Baqir, R. and Easterly, W. (1999) Public goods and ethnic divisions. Quarterly Journal of Economics 114(4): 1243-1284.

Alesina, A., Baqir, R. and Easterly W. (2000) Redistributive public employment. Journal of Urban Economics 48: 219-241.

Alesina, A., Devleschawuer, A., Easterly, W., Kurlat, S. and Wacziarg R. (2003) Fractionalization. Journal of Economic Growth 8(2): 155-194.

Alesina, A. and Giuliano, P. (2009) Preferences for redistribution. Working Paper 14825, NBER, Cambridge, MA.

Alesina, A. and Glaeser, E. (2004) Fighting Poverty in the U.S. and in Europe: A World of Difference. New York: Oxford University Press.

Alesina, A., Glaeser, E. and Sacerdote B. (2001) Why doesn't the U.S. have a European-style welfare system? Brookings Papers on Economic Activity 2: 187-254.

Alesina, A. and La Ferrara, E. (2000) Participation in heterogeneous communities. Quarterly Journal of Economics 115(3): 847-904.

Alesina, A. and La Ferrara, E. (2002) Who trusts others? Journal of Public Economics 85: 207-234.

Alesina, A. and La Ferrara, E. (2005a) Ethnic diversity and economic performance. Journal of Economic Literature 43: 762-800.

Alesina, A. and La Ferrara, E. (2005b) Preferences for redistribution in the land of opportunities. Journal of Public Economics 89(5-6): 897-931.

Algan, Y. and Cahuc, P. (2009) Civic virtue and labor market institutions. American Economic Journal: Macroeconomics 1(1): 111-145.

Annett, A. (2001) Social fractionalization, political instability, and the size of government. IMF Staff Papers 48(3): 561-592.

Arcand, J.-L., Guillaumont, P. and Guillaumont Jeanneney, S. (2000) How to make a tragedy: on the alleged effect of ethnicity on growth. Journal of International Development 12: 925-938.

Banting, K., Johnston, R., Kymlicka, W. and Soroka, S. (2007) Do multiculturalism policies erode the welfare state? An empirical analysis. In W. Kymlicka and K. Banting (eds.), Multiculturalism and the Welfare State: Recognition and Redistribution in Contemporary Democracies. Oxford; New York: Oxford University Press.

Journal of Economic Surveys (2013) Vol. 27, No. 2, pp. 364-389

(C) 2011 Blackwell Publishing Ltd 
Banting, K. and Kymlicka, W. (2004) Do multiculturalism policies erode the welfare state? In P. Van Parijs (ed.), Cultural Diversity Versus Economic Solidarity, Brussels: De Boeck.

Banting, K.G. (2005) Multiculturalism and the welfare state: Recent evidence about ethnic diversity, multiculturalism policies and redistribution. Unpublished, Queen's University.

Bénabou, R. and Ok, E.A. (2001) Social mobility and the demand for redistribution: the POUM hypothesis. Quarterly Journal of Economics 116(2): 447-487.

Bertrand, M. and Mullainathan, S. (2004) Are Emily and Greg more employable than Lakisha and Jamal? A field experiment on labor market discrimination. American Economic Review 94(4): 991-1013.

Böheim, R. and Mayr, K. (2005) Immigration and public spending. Discussion paper 1834, IZA, Bonn.

Borck, R. (2007) Voting, inequality, and redistribution. Journal of Economic Surveys 21(1): 90-109.

Bornhorst, F., Ichino, A., Kirchkamp, O., Schlag, K.H. and Winter, E. (2010) Similarities and differences when building trust: the role of cultures. Experimental Economics 13: 260-283.

Bossert, W., D'Ambrosio, C. and La Ferrara, E. (2006) A generalized index of fractionalization. Technical report, IGIER - Università Bocconi.

Bouckaert, J. and Dhaene, G. (2004) Inter-ethnic trust and reciprocity: results of an experiment with small businessmen. European Journal of Political Economy 20: 869-886.

Brock, W.A. and Durlauf, S.N. (2000) Growth economics and reality. Working paper 8041, NBER.

Brown, R. (2000) Social Identity Theory: past achievements, current problems and future challenges. European Journal of Social Psychology 30: 745-778.

Brown, R. (2010) Prejudice: Its Social Psychology (2nd edn.) Chichester: Wiley-Blackwell.

Bruk, S.I. and Apenchenko, V.S. (eds.) (1964) Atlas Narodov Mira. Moscow: Glavnoe upravlenie geodezii i kartografii gosudarstvennogo geologicheskogo komiteta SSSR and Institut etnografii im. H. H. Miklukho-Maklaia, Akademiia nauk SSSR.

Carlsson, M. and Rooth, D.-O. (2007) Evidence of ethnic discrimination in the Swedish labor market using experimental data. Labour Economics 14: 716-729.

Chandra, K. (2001) Cumulative findings in the study of ethnic politics. apsa-cp (Newsletter of the Organized Section in Comparative Politics of the American Political Science Association) 12(1): 7-11.

Chen, Y. and Li, S. X. (2009) Group identity and social preferences. American Economic Review 99: 431-57.

Collier, P. (2001) Implications of ethnic diversity. Economic Policy 32: 129-166.

Corneo, G. (2001) Inequality and the state: comparing U.S. and German preferences. Annales d'Economie et de Statistique 63-64: 283-296.

Corneo, G. and Grüner, H.P. (2000) Social limits to redistribution. American Economic Review 90(5): 1491-1507.

Corneo, G. and Grüner, H.P. (2002) Individual preferences for political redistribution. Journal of Public Economics 83(1): 83-107.

Costa, D.L. and Kahn, M.E. (2003) Understanding the American decline in social capital, 1952-1998. Kyklos 56: $17-46$.

Cutler, D.M., Elmendorf, D.W. and Zeckhauser, R. (1993) Demographic characteristics and the public bundle. Public Finance 48: 178-198.

Dahlberg, M. and Edmark, K. (2008) Is there a 'race-to-the-bottom' in the setting of welfare benefit levels? Evidence from a policy intervention. Journal of Public Economics 92(92): 1193-1209.

Dahlberg, M., Edmark, K. and Lundqvist, H. (2011) Ethnic diversity and preferences for redistribution. IFN Working Paper No. 860, Research Institute of Industrial Economics, Stockholm.

Durlauf, S.N. (2001) [Why doesn't the United States have a European-style welfare state?]. Comments and discussion. Brookings Papers on Economic Activity, 2001(2): 255-277.

Easterly, W. and Levine, R. (1997) Africa's growth tragedy: Policies and ethnic divisions. Quarterly Journal of Economics 111(4): 1203-1250.

Eckel, C.C. and Grossman, P.J. (2001) Chivalry and solidarity in ultimatum games. Economic Inquiry 39: 171-188.

Edin, P.-A., Fredriksson, P. and Aslund O. (2003) Ethnic enclaves and the economic success of immigrants - evidence from a natural experiment. The Quarterly Journal of Economics 118: 329-357.

Eger, M.A. (2010) Even in Sweden: the effect of immigration on support for welfare state spending. European Sociological Review 26(2): 203-217. 
Falk, A. and Heckman, J.J. (2009) Lab experiments are a major source of knowledge in the social sciences. Science 326(5952): 535-538.

Falk, A. and Zehnder, C. (2007) Discrimination and in-group favoritism in a citywide trust experiment. Discussion paper 2765, IZA, Bonn.

Fearon, J. (2003) Ethnic and cultural diversity by country. Journal of Economic Growth 8(2): 195-222.

Fedderke, J., Luiz, J. and de Kadt, R. (2008) Using fractionalization indexes: deriving methodological principles for growth studies from time series evidence. Social Indicators Research 85: 257-278.

Fershtman, C. and Gneezy, U. (2001) Discrimination in a segmented society: an experimental approach. Quarterly Journal of Economics 116: 351-377.

Finseraas, H. (2008) Immigration and preferences for redistribution: an empirical analysis of European survey data. Comparative European Politics 6(4): 407-431.

Finseraas, H. (2009) Income inequality and demand for redistribution: a multilevel analysis of European public opinion. Scandinavian Political Studies 32(1): 92-119.

Fong, C.M., Bowles, S. and Gintis, H. (2006) Strong reciprocity and the welfare state. In S. Kolm and J. Mercier-Ythier (eds.), Handbook on the Economics of Giving, Altruism, and Reciprocity, Vol. 2, pp. 1439-1464. Amsterdam: Elsevier.

Fong, C.M. and Luttmer, E.F.P. (2009) What determines giving to hurriance Katrina victims? Experimental evidence on racial group loyalty. American Economic Journal: Applied Economics 1: 64-87.

Geertz, C. (1963) The integrative revolution: primordial sentiments and civil politics in the new states. In Old Societies and New States: The Quest for Modernity in Asia in Africa, pp. 105-57. New York: Free Press of Glencoe. Reprinted in Geertz C. (1973) The Interpretation of Cultures: Selected Essays. pp. 255-310. New York: Basic Books.

Gerdes, C. (2011) The impact of immigration on the size of government: empirical evidence from Danish municipalities. Scandinavian Journal of Economics, forthcoming.

Gerdes, C. and Wadensjö, E. (2008) The impact of immigration on election outcomes in Danish municipalities. Discussion paper 3586, IZA, Bonn.

Gilens, M. (1995) Racial attitudes and opposition to welfare. Journal of Politics 57(4): 994-1014.

Gilens, M. (1996) "Race coding" and white opposition to welfare. American Political Science Review 90(3): 593-604.

Gilens, M. (1999) Why Americans Hate Welfare: Race, Media, and the Politics of Anti-Poverty Policy. Chicago: University of Chicago Press.

Gitlin, T. (1996) The Twilight of Common Dreams: Why America Is Wracked by Culture Wars. New York: Owl Books.

Glaeser, E.L., Laibson, D.I., Scheinkman, J.A. and Soutter, C.L. (2000) Measuring trust. Quarterly Journal of Economics 115: 811-846.

Goette, L., Huffman, D. and Meier, S. (2006) The impact of group membership on cooperation and norm enforcement: evidence using random assignment to real social groups. American Economic Review 96: 212-216.

Goldin, C. and Katz, L. (1999) Human capital and social capital: the rise of secondary schooling in America, 1910 to 1940. Journal of Interdisciplinary History 29(4): 683-723.

Goodhart, D. (2006) Progressive Nationalism. London: Demos.

Green, E. D. (2004) The (mis)use of ethnicity in current political economy literature: conceptual and data issues. Paper prepared for WIDER conference on Making Peace Work, Helsinki, 4-5 June 2004.

Güth, W., Levati, M.V. and Ploner, M. (2008) Social identity and trust: an experimental investigation. Journal of Socio-Economics 37(4): 1293-1308.

Habyarimana, J., Humphreys, M., Posner, D.N. and Weinstein, J. (2007) Why does ethnic diversity undermine public goods provision? American Political Science Review 101(4): 709-725.

Haile, D., Sadrieh, A. and Verbon, H.A.A. (2008) Cross-racial envy and underinvestment in South African partnerships. Cambridge Journal of Economics 32: 703-724.

Henrich, J., Boyd, R., Bowles, S., Camerer, C., Fehr, E., Gintis, H. and McElreath, R. (2001) In search of Homo Economicus: behavioral experiments in 15 small-scale societies. American Economic Review Papers and Proceedings 91: 73-78. 
Hopkins, D.J. (2009) The diversity discount: when increasing ethnic and racial diversity prevents tax increases. The Journal of Politics 71(1): 160-177.

Hopkins, D.J. (2010) Politicized places: explaining where and when immigrants provoke local opposition. American Political Science Review 104(1): 40-60.

Hopkins, D.J. (2011a) The limited local impacts of ethnic and racial diversity. American Politics Research 39(2): 344-379.

Hopkins, D.J. (2011b) National debates, local responses: the origins of local concern about immigration in Britain and the United States. British Journal of Political Science 41(3): 499-524.

Hungerman, D.M. (2008) Race and charitable church activity. Economic Inquiry 46: 380-400.

Hungerman, D.M. (2009) Crowd-out and diversity. Journal of Public Economics 93: 729-740.

James, E. (1987) The public/private division of responsibility for education: an international comparison. Economics of Education Review 6(1): 1-14.

James, E. (1993) Why do different countries choose a different public-private mix of educational services? Journal of Human Resources 28(3): 571-592.

Keely, L.C. and Tan, C.M. (2008) Understanding preferences for income redistribution. Journal of Public Economics 92: 944-961.

Klor, E.F. and Shayo, M. (2010) Social identity and preferences over redistribution. Journal of Public Economics 94: 269-278.

Knack, S. and Keefer, P. (1997) Does social capital have an economic payoff? A cross-country investigation. Quarterly Journal of Economics 112: 1251-1288.

Kuijs, L. (2000) The impact of ethnic heterogeneity on the quantity and quality of public spending. Working Paper 00/49, International Monetary Fund, Washington, DC.

Laitin, D. and Posner, D. (2001) The implications of constructivism for constructing ethnic fractionalization indices. apsa-cp (Newsletter of the Organized Section in Comparative Politics of the American Political Science Association) 12(1): 13-17.

Lee, W. and Roemer, J.E. (2006) Racism and redistribution in the United States: a solution to the problem of American expectionalism. Journal of Public Economics 90: 1027-1052.

Levinson, D. (1998) Ethnic Groups Worldwide: A Ready Reference Handbook. Phoenix: Oryx Press.

Levitt, S.D. and List, J.A. (2007) What do laboratory experiments measuring social preferences reveal about the real world? Journal of Economic Perspectives 21: 153-174.

Lind, J. T. (2007) Fractionalization and the size of government. Journal of Public Economics 91: 51-76.

Longhi, S., Nijkamp, P. and Poot, J. (2005) A meta-analytic assessment of the effect of immigration on wages. Journal of Economic Surveys 19(3): 451-477.

Longhi, S., Nijkamp, P. and Poot, J. (2009) Regional economic impacts of immigration: a review. Discussion Paper 047/3, Tinbergen Institute, Amsterdam.

Luttmer, E.F.P. (2001) Group loyalty and the taste for redistribution. Journal of Political Economy 109(3): $500-528$.

Mayr, K. (2007) Immigration and income redistribution: a political economy analysis. Public Choice 131: $101-116$.

McCarty, T. (1993) Demographic diversity and the size of the public sector. Kyklos 46(2): 225-240.

Meltzer, A.H. and Richard, S.F. (1981) A rational theory of the size of government. Journal of Political Economy 89(5): 914-927.

Minority Rights Group (ed.) (1997) World Directory of Minorities (2nd edn.) London: Minority Rights Group International.

Montalvo, J.G. and Reynal-Querol, M. (2005a) Ethnic diversity and economic development. Journal of Development Economics 76: 293-323.

Montalvo, J.G. and Reynal-Querol, M. (2005b) Ethnic polarization, potential conflict, and civil wars. American Economic Review 95: 796-816.

Mueller, D.C. and Murrell, P. (1986) Interest groups and the size of government. Public Choice 48: 125-145.

Nannestad, P. (2007) Immigration and welfare states: a survey of 15 years of research. European Journal of Political Economy 23: 512-532.

Okkerse, L. (2008) How to measure labour market effects of immigration: a review. Journal of Economic Surveys 22(1): 1-30. 
Persson, T. and Tabellini, G. (2000) Political Economics: Explaining Economic Policy. Cambridge, MA: MIT Press.

Piketty, T. (1995) Social mobility and redistributive politics. Quarterly Journal of Economics 110(3): 551-584.

Posner, D. (2002) Ethnic fractionalization in Africa: how should it be measured? What does it explain about economic growth? Unpublished working paper, University of California, Los Angeles.

Posner, D. (2004a) The implications of constructivism for studying the relationship between ethnic diversity and economic growth. Unpublished working paper, University of California, Los Angeles.

Posner, D. (2004b) Measuring ethnic fractionalization in Africa. American Journal of Political Science 48(4): $849-863$.

Poterba, J.M. (1997) Demographic structure and the political economy of public education. Journal of Policy Analysis and Management 16(1): 48-66.

Poterba, J.M. (1998) Demographic change, intergenerational linkages, and public education. American Economic Review Papers and Proceedings 88: 315-320.

Ravallion, M. and Lokshin, M. (2000) Who wants to redistribute? The tunnel effect in 1990s Russia. Journal of Public Economics 76: 87-104.

Razin, A., Sadka, E. and Swagel, P. (2002) Tax burden and migration: a political economy theory and evidence. Journal of Public Economics 85: 167-190.

Reynal-Querol, M. (2002) Ethnicity, political systems, and civil wars. Journal of Conflict Resolution 46(1): $29-54$.

Ribar, D.C. and Wilhelm, M.O. (1999) The demand for welfare generosity. The Review of Economics and Statistics 81: 96-108.

Roemer, J., Lee, W., and Van der Straeten, K. (2007) Racism, xenophobia and distribution: a study of multiissue politics in advanced democracies. Cambridge, MA/New York: Harvard University Press/Russell Sage Foundation Press.

Roemer, J.E. (1998) Why the poor do not expropriate the rich: an old argument in new garb. Journal of Public Economics 70(3): 399-424.

Roemer, J.E. and Van der Straeten, K. (2005) Xenophobia and distribution in France: a politico-economic analysis. Journal of Economics 86(1478): 95-144.

Roemer, J.E. and Van der Straeten, K. (2006) The political economy of xenophobia and distribution: the case of Denmark. Scandinavian Journal of Economics 108: 251-278.

Rowthorn, R. (2008) The fiscal impact of immigration on the advanced economies. Oxford Review of Economic Policy 24(3): 560-580.

Rushton, M. (2008) A note on the use and misuse of the racial diversity index. Policy Studies Journal 36: $445-459$.

Selway, J.S. (2011) The measurement of cross-cutting cleavages and other multidimensional cleavage structures. Political Analysis 19: 48-75.

Senik, C. (2004) When information dominates comparison: learning from Russian subjective panel data. Journal of Public Economics 88: 2099-2123.

Senik, C. (2005) Income distribution and well-being: what can we learn from subjective data? Journal of Economic Surveys 19: 43-63.

Senik, C. (2006) Ambition et jalousie : la perception du revenu d'autrui dans la "vieille Europe", la "nouvelle Europe" et les Etats-Unis. Revue économique 57: 645-653.

Senik, C. (2008) Ambition and jealousy: income interactions in the Old Europe versus the New Europe and the United States. Economica 75: 495-513.

Senik, C., Stichnoth, H. and Van der Straeten, K. (2009) Immigration and natives' attitudes towards the welfare state: evidence from the European Social Survey. Social Indicators Research 91: $345-370$.

Shayo, M. (2009) A model of social identity with an application to political economy: nation, class, and redistribution. American Political Science Review 103(2): 147-174.

Soroka, S., Banting, K. and Johnston, R. (2006) Immigration and redistribution in a global era. In P. Bardhan, S. Bowles and M. Wallerstein (eds.), Globalization and Egalitarian Redistribution. Princeton, NJ: Princeton University Press. 
Soroka, S.N., Johnston, R. and Banting, K. (2004) Ethnicity, trust, and the welfare state. In P. Van Parijs (ed.), Cultural Diversity versus Economic Solidarity, Brussels: De Boeck.

Stichnoth, H. (2011) Does immigration weaken natives' support for the unemployed? Evidence from Germany. Public Choice, forthcoming.

Tajfel, H., Billig, M., Bundy, R. and Flament, C. (1971) Social categorization and intergroup behavior. European Journal of Social Psycholoy 1: 149-177.

Van den Berghe, P.L. (1981) The Ethnic Phenomenon. New York: Elsevier.

Van den Berghe, P.L. (1986) Ethnicity and the sociobiology debate. In J. Rex and D. Mason (eds.), Theories of Race and Ethnic Relations, pp. 246-263. Cambridge: New York: Cambridge University Press.

Van den Berghe, P.L. (1995) Does race matter? Nations and Nationalism 1(3): 357-368.

Van Parijs, P. (2004) Cultural diversity versus economic solidarity. Brussels: De Boeck.

Vernby, K. and Finseraas, H. (2010) Xenophobia and left voting. Politics \& Society 38: 490-516.

Vigdor, J.L. (2002) Interpreting ethnic fragmentation effects. Economics Letters 75: 271-276.

Yeoh, K.K. (2001) Towards an index of ethnic fractionalization. Working Paper 2001-3, University of Malaysia, Faculty of Economics and Administration, Kuala Lumpur. 